\title{
Investigation of the factors contributing to truck driver's involvement in an injury accident
}

\author{
Kamyon sürücüsünün dahil olduğu yaralanmalı kazalara etki eden \\ faktörlerin incelenmesi
}

\author{
Ibrahim Khalil UMAR ${ }^{*}$ iD , Samir BASHIR ${ }^{2}$ iD \\ 1Department of Civil Engineering, Faculty of Civil and Environmental Engineering, Near East University, KKTC, Turkey. \\ ikumar@kanopoly.edu.ng \\ 2Department of Civil Engineering Technology, School of Technology, Kano State Polytechnic, Kano, Nigeria. \\ smgbash@gmail.com
}

\begin{abstract}
The study was aimed at identifying the factors contributing to truck driver's involvement in an injury accident in Kano, Nigeria using Logistic regression. 248 truck drivers were interviewed using a questionnaire and relevant information on their involvement in injury accident was collected. The result of the survey shows that $52.8 \%$ of the drivers were involved in an injury accident at least once in their professional carrier and $80 \%$ of the drivers were below the age of 40years. Results from the regression analysis found the Average distance traveled/week ( $p=0.0057)$, average driving hours/day $(p=0.0232)$, sleeping on the wheel $(p=0.0004)$, and presence of co-driver $(p=0.0003)$ to be statistically significant in contributing to driver's involvement in an injury accident. Average distance traveled/week, sleeping on wheel and presence of co-driver were found to positively affect involvement in injury accident with $O R$ values of 1.80, 3.61 and 3.94 respectively. The model was found to be good in classifying truck drivers' involvement in injury accident with a reasonable level of accuracy (70\%). Increased safety awareness among drivers by conducting seminars and organizing training sessions regularly will help reduce the involvement of truck drivers in accidents.
\end{abstract}

Keywords: Accident, Injury, Logistic regression, Truck driver.

\section{Öz}

Bu çalıșma, lojistik regresyon kullanarak Kano, Nijerya'da kamyon sürücülerinin karıştıkları yaralanmalı kazaların oluşumuna katkıda bulunan faktörleri tanımlamayı amaçlamaktadır. Calıșmada, 248 kamyon șoförü ile anket yapılmıs ve yaralanmalı kazalara katkıları ile ilgili bilgiler toplanmıştır. Anketin sonucndau, sürücülerin \%52.8'inin profesyonel kariyerlerinde en az bir kez yaralanmalı kaza geçirdiklari ve sürücülerin \%80'inin 40 yaşın altında olduğu görülmüștür. Regresyon analizinden elde edilen sonuçlara göre; ortalama gidilen mesafe/hafta ( $p=0.0057)$, ortalama sürüş süresi/günü $(p=0.0232)$, direksiyonda uyumak ( $p=0.0004)$ ve yardımcı sürücünün olması $(p=0.0003)$ faktörlerinin sürücünün yaralanmalı trafik kazasına karışmasına istatistiksel olarak anlamlı katkılarda bulunduğu anlassılmıștır. Gidilen ortalama mesafe / hafta, direksiyonda uyumak ve yardımcı sürücünün olması'nın OR değerleri sırasıyla 1.80, 3.61 ve 3.94 değerlerine sahiptir ve yaralanma kazaları artırıcı yönde etkilediği saptanmıştır. Bu model; kamyon sürücülerinin yaralanmalı trafik kazalarına karıșmalarını incelemede bașarılı bulunmuș olup, modelin kabul edilebilir bir güven seviyesinde çalıștığı görülmüștür (\%70). Sürücüler arasında seminerler ve düzenli eğitimler tertip edilerek trafik güvenliği bilincinin arttırılması, kamyon sürücülerinin yaralanmalı trafik kazalarına karışmalarını azaltmaya yardımcı olacaktır.

Anahtar kelimeler: Kaza, Yaralanmal,, Lojistik regresyon, Kamyon sürücüsü.

\section{Introduction}

Road Traffic Accidents (RTA) has become an urgent problem in recent years due to an increasing number of vehicles and traffic density [1]. Several researchers have tried to establish a predictive model that identifies possible explanatory factors, such as traffic characteristics, road environment, and human error, for the probability of the traffic crash [2]. In Nigeria, RTA is among the major socioeconomic challenges claiming many lives and properties every year. In the year 2016, about 65,467 people were reported to have been involved in RTA, out of which 5053 died and 30105 suffered various degrees of injuries. $20.7 \%(n=15,682)$ of the vehicles involved in the RTA were heavy vehicles [3].

Truck accidents are mostly associated with high severity. More than half of the truck crashes involve fatal or major injuries and the truck drivers were found to be at fault in at least $80 \%$ of the cases [4]. Drivers of heavy vehicles have higher chances of been involved in a severe traffic accident because the weight of their vehicle makes the braking distance to be longer. The fatality rate and property loss of truck-related accident are also high [5]. Questionnaire studies on truck driver's involvement in RTA in Tanzania show that about $40 \%$ of drivers were victims of a traffic accident at least once during their career and $45 \%$ were involved in fatal crashes [6]. Catarino et al reported 37\% involvement in RTA by truck drivers for a study conducted in Portugal [7]. Truck and heavy vehicle drivers constitute $20 \%$ of all worker fatalities in Australia during the previous decade [8]. Truck drivers and driver/Sales workers represent $17 \%$ of all occupational fatalities in the United States [5]

Hours driving, truck type (rigid or articulated), driving time (midnight, evening, morning), and drivers experience significantly affect truck driver's involvement in traffic crash [9]. The pattern of the truck driver's involvement in traffic accidents varies according to age, fatigue, distance travelled, driving experience, and vehicle type [5]. Another research

${ }^{*}$ Corresponding author/Yazışılan Yazar 
identified distance travelled, driver training, employment type, payment method, vehicle type, scheduling practices, working hours as factors influencing the safety of truck drivers [10].

Several attempts were made using different methods to investigate the influence of driver's attribute, accident characteristics, road geometry, and traffic density on the severity of RTA [11]. Majority of the modeling approaches were framed in the discrete response models which include: binary response models (e.g., binary probit and binary logit), ordered discrete response models (e.g. bivariate ordered probit and generalized ordered logit), unordered multinomial discrete response models (e.g. multinomial logit, Markov switching multinomial logit, nested logit, and mixed logit); other less common approaches have also been used and include: artificial neural networks, and some data mining techniques such as the classification and regression tree analysis. The choice of methodological approach used in accident analysis depends mainly on the available data set, quantity and quality of the data, and other data-specific characteristics [12]. Despite the methodological evolution registered, which improved the statistical validity of findings, logistic regression models are still broadly employed in the identification of contributing factors to accident severity [11]. For example, Logistic regression was used to identify the factors behind fatal and non-fatal road crashes in Lahore, Pakistan. The model found Speeding and overloading as the major causes of fatal crashes [13]. Karacasu et al also used logistic regression and discriminant analysis in estimating the causes of traffic accidents in Eskisehir, Turkey and found the logistic regression to classify injury and non-injury accident with up $72 \%$ accuracy [14]. The influence of road features, vehicle attributes, environmental factors, crash characteristics and driver particulars on hit-and-run crashes in Singapore were found to be estimated efficiently using Logistic regression [15]. Logistic regression analysis was performed, with driver and crash characteristics as predictors of the crash category in quantifying sleep-related crashes on the low-speed road. A conservative $\mathrm{p}$-value of 0.001 determined the statistical significance of the predictors [16]. Three level logistic regression models were built to test the association between driver, collision, roadway, and commercial vehicle risk factors; proximity to the nearest rest area, weigh station, or truck stop; and the outcome of a sleepiness/ fatigue-related at-fault commercial vehicle crash [17]. Effects of personality traits, mental illness and driving behaviour on driver's involvement in accidents were evaluated using Logistic regression and found anxiety and depression to significantly increase chances of involvement by 2.4 and 2.7 respectively [18]. Logistic regression was used to develop a model to examine the influence of the explanatory variable on the injury severity of motorcycle crashes in Carolina [19].

Analysis of road traffic accident in Kano metropolitan revealed that 3 people are killed and 18 more get injured for every 7 Road traffic accident reported, and $10 \%$ of all traffic accidents $(\mathrm{n}=978)$ are truck related which happen to be more severe than other forms of RTA [20]. This is due to the commercial activities taking place in the state where a large number of trucks flows in and out of the state from all the northern states and the neighbouring countries of Niger, Chad, and Cameroun [21]. It is found to be necessary to investigate the factors contributing to the truck driver's involvement in an injury accident in the state in order to come up with safety countermeasures that will reduce truck driver's involvement in
RTA. The objective of the research is to identify the factors that affect the probability of a truck driver's involvement in Injury accident in Nigeria.

Binary logistic regression was found to be suitable for this research because the model uses data from a variety of predictors to model the probability of each of the two possible outcomes which in this case are driver's involvement or non-involvement in an injury accident. Binary logistic regression has been successfully used to model factors and causes of various traffic accident problems with an acceptable level of accuracy [13]-[17].

\section{Materials and method}

Kano State is an industrial and business base centre in the Northern part of Nigeria as well as being the biggest city, in Nigeria. It has a population of 9,383,682 as at census 2006 , and last known population is approximately $11,087,800$ (the year 2011), this was $6.77 \%$ of Nigeria's population with an annual growth rate of $3.36 \%$. The state is bounded to the North West by Katsina State, to the South West by Kaduna and to the North East by Jigawa State, while to the South East by Bauchi State as shown in Figure 1. Road transportation is the dominant mode of transport which linked Kano with most of the neighbouring African cities. Convoys of heavy trucks, buses, and others connect it with various municipalities in Chad, Cameroon, Niger, and Republic of Benin [22].

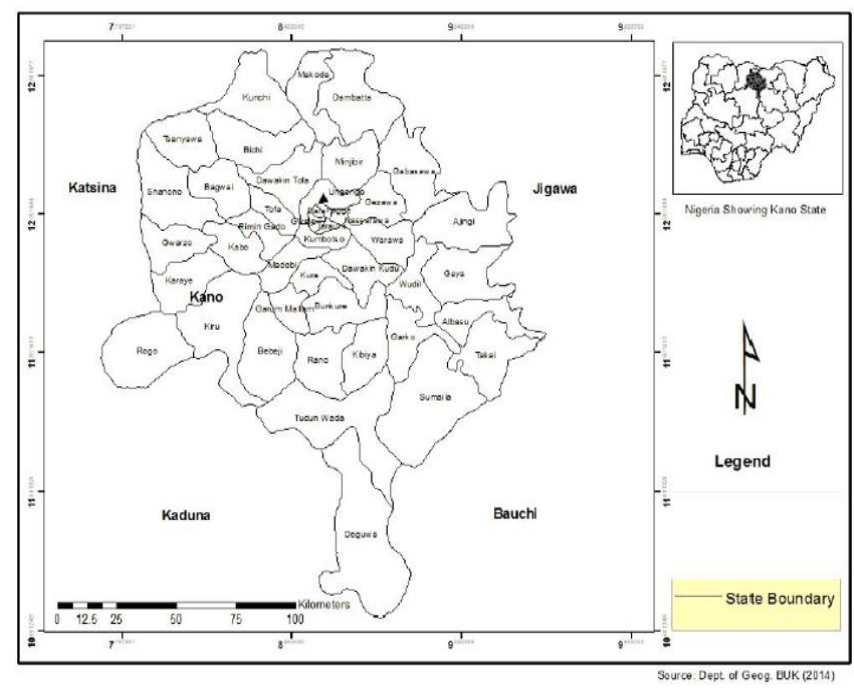

Figure 1. Map of Kano State.

The research was conducted in Kano State Nigeria by interviewing 248 male truck drivers in January 2018. Drivers of different truck categories were randomly selected and interviewed using a short-structured questionnaire. The demographic characteristics of the driver, type of the truck driving, driving experience, drivers' license, average distance covered in a week, average daily driving hours, whether the driver sleeps on wheels or not, presence of co-driver, and information on driver's involvement in injury accident were collected. The dependent variable Y represents truck drivers' involvement in an injury accident and is binary in nature.

$Y=\left\{\begin{array}{l}0, \text { if the truck driver is not involved in an injury accident } \\ 1, \text { if the truck driver is involved in injury accident }\end{array}\right.$

The independent variables were categorical and are given values 1, 2, 3 as summarised in Table 1 . 
Table 1. Variable description and notations.

\begin{tabular}{|c|c|c|}
\hline Variables & Notations & Description \\
\hline $\begin{array}{l}\text { Involvement in } \\
\text { Injury Accident }\end{array}$ & Y & $0=$ not involved $1=$ involved \\
\hline Age & $\mathrm{X}_{1}$ & $\begin{array}{c}1=18 \text { To } 25,2=26 \text { To } 30,3=31 \\
\text { To } 35,4=36 \text { To } 40,5=>40\end{array}$ \\
\hline Education & $\mathrm{X}_{2}$ & $\begin{array}{c}\text { 1=Informal Education, } \\
\text { 2=Primary, 3=Secondary, } \\
\text { 4=Diploma, 5=Degree }\end{array}$ \\
\hline License & $\mathrm{X}_{3}$ & $0=$ No, $1=$ Yes \\
\hline Driving Experience & $\mathrm{X}_{4}$ & $\begin{array}{c}1=0 \text { To } 5,2=6 \text { To } 10,3=11 \text { To } \\
15,4=16 \text { To } 20,5=>20\end{array}$ \\
\hline $\begin{array}{c}\text { Average } \\
\text { distance/week }\end{array}$ & $\mathrm{X}_{5}$ & $\begin{array}{c}1=<2000 \mathrm{~km}, 2=2000-4000 \mathrm{~km}, \\
3=\geq 4000 \mathrm{~km}\end{array}$ \\
\hline Hours driving/day & $\mathrm{X}_{6}$ & $1=<5 \mathrm{hrs}, 2=5-9 \mathrm{hrs}, 3=>9 \mathrm{hrs}$ \\
\hline $\begin{array}{l}\text { Number of Days } \\
\text { driving/week }\end{array}$ & $\mathrm{X}_{7}$ & 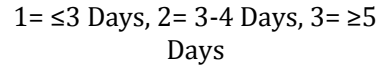 \\
\hline Type of vehicle & $\mathrm{X}_{8}$ & $\begin{array}{c}1=\text { Tanker, } 2=\text { Tipper, } 3=\text { Trailer, } \\
4=\text { Luxurious Bus }\end{array}$ \\
\hline Sleeping on Wheel & $\mathrm{X}_{9}$ & $0=\mathrm{NO}, 1=\mathrm{YES}$ \\
\hline $\begin{array}{l}\text { Hours } \\
\text { sleeping/day }\end{array}$ & $\mathrm{X}_{10}$ & $1=\leq 3 \mathrm{HRS}, 2=4 \mathrm{HRS}, 3=\geq 6 \mathrm{HRS}$ \\
\hline Co-driver & $\mathrm{X}_{11}$ & $0=\mathrm{NO}, 1=\mathrm{YES}$ \\
\hline
\end{tabular}

\subsection{Logistic regression}

Logistic regression is used in modeling discrete response variables, especially for a binary response variable. The elementary principle of logistic regression is to obtain the probability of an event by studying the correlation between the dependant and explanatory variables. When the predicted probability of an event is at least 0.5 , then it is regarded to be in the first group, i.e., event; else, as the second group, i.e., no event [23]. The independent variables can either be categorical or continuous in binary logistic regression. Binary logistic regression was used in testing the significance of the factors contributing to road accident when the dependent variable is binary [14],[15],[24]. In this study the independent variables are categorical and the response variables Y representing truck drivers' involvement in injury accident is binary and this makes binary logistic regression approach suitable for the study. The binary logistic regression model is expressed by equation 1 .

$$
\operatorname{Logit}(\mathrm{p})=\operatorname{Ln}\left(\frac{p}{1-p}\right)=b_{0}+b_{1} x_{1}+b_{2} x_{2}+\ldots,+b_{i} x_{i}
$$

$\mathrm{p}$ is the probability of driver been involved in injury accident, $b_{0}$ is the intercept, $b_{i}$ are the model coefficients of the independent variables, and $x_{i}$ are independent variables.

The Odd ratio (OR) is equal to exp $\left(b_{i}\right)$; OR is the factor indicating how an independent variable increases or decreases chances of the truck driver's involvement in injury accident when all other variables remain unchanged. Values greater than 1 indicate increase and OR values less than 1 indicates a decrease when the value of the corresponding independent variable increases by a unit [9],[13],[14].

\section{Results}

The descriptive statistics of the respondents and their involvement in injury accident was given in Table $2.52 .8 \%$ of the drivers interviewed were involved in an injury accident and $47.18 \%$ were not involved. $68 \%$ of those involved in injury accident are youth between the age of $26-40$ years, $53 \%$ have obtained secondary school certificate. $81 \%$ have drivers' license, $66 \%$ covered at least $2.000 \mathrm{~km}$ in a week. $58 \%$ of the drivers sleep at least $6 \mathrm{hrs}$ a day and $88 \%$ have co-drivers. proportion levels of the study variables were presented in Figure 2.

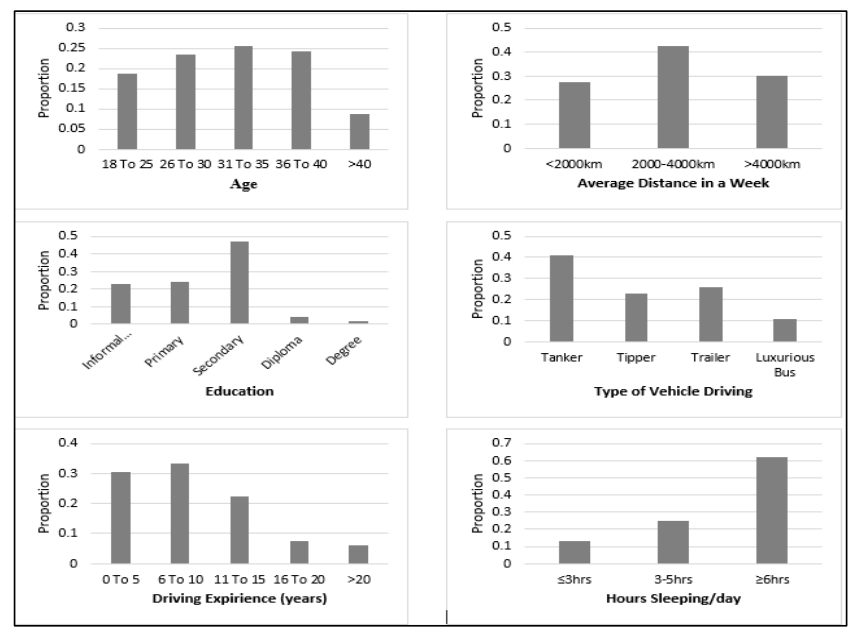

Figure 2. Study variables.

Figure 3 and 4 show the graphical assessment of the fit to the binary logistic model developed in the study. The graphs show that the model appears to fit the data reasonably.

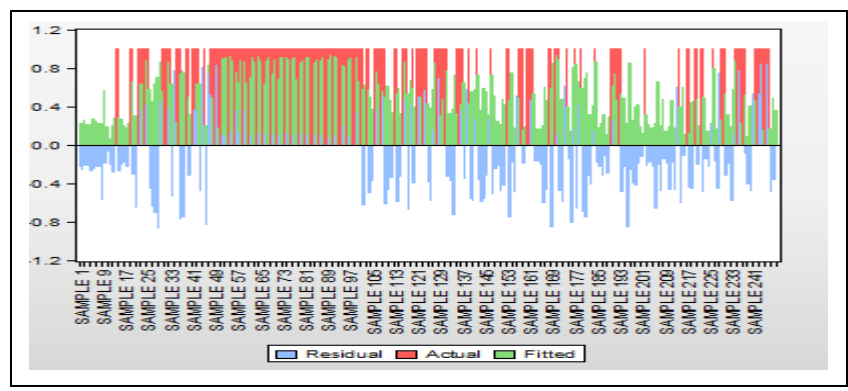

Figure 3. Actual, fitted and residual.

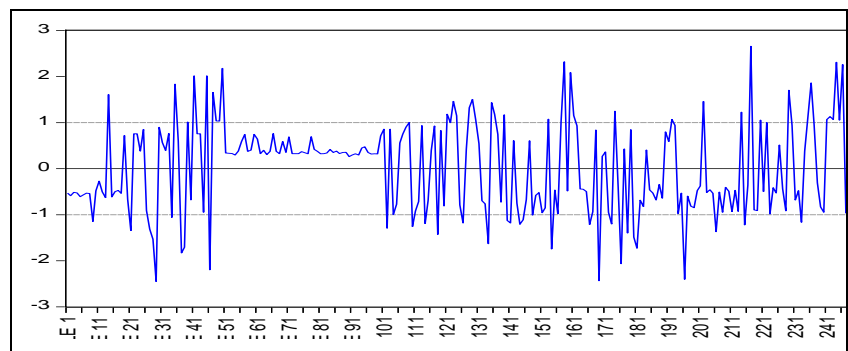

Figure 4. Standardized (Pearson) residual.

Binary logistic regression analysis was performed to determine the statistical significance of the predictor variables and the rates at which they increase or decrease the chances of diver's involvement in an injury accident. The result was summarised in Table 3 and the goodness of fit of the model in Table 4. 
Table 2. Data Summary of the Predictor Variables(n=248).

\begin{tabular}{|c|c|c|c|c|}
\hline \multirow[t]{2}{*}{ Variables } & \multirow[t]{2}{*}{ Label } & \multirow{2}{*}{$\begin{array}{c}\text { Respondents } \\
\%\end{array}$} & \multicolumn{2}{|c|}{ Involvement in Injury Accident (\%) } \\
\hline & & & Involved & Not Involved \\
\hline \multirow[t]{4}{*}{ Involvement in accident } & Yes & 52.82 & & \\
\hline & No & 47.18 & & \\
\hline & 18 To 25 & 18.55 & 20.61 & 16.24 \\
\hline & 26 To 30 & 23.39 & 20.61 & 26.50 \\
\hline \multirow[t]{5}{*}{ Age } & 31 To 35 & 25.40 & 25.19 & 25.64 \\
\hline & 36 To 40 & 24.19 & 22.14 & 26.50 \\
\hline & $>40$ & 8.47 & 11.45 & 5.13 \\
\hline & Informal Education & 22.98 & 20.61 & 25.64 \\
\hline & Primary & 24.19 & 19.08 & 29.91 \\
\hline \multirow[t]{4}{*}{ Education } & Secondary & 46.77 & 53.44 & 39.32 \\
\hline & Diploma & 4.44 & 5.34 & 3.42 \\
\hline & Degree & 1.61 & 1.53 & 1.71 \\
\hline & No & 18.55 & 12.98 & 24.79 \\
\hline \multirow{3}{*}{ License } & Yes & 81.45 & 87.02 & 75.21 \\
\hline & 0 To 5 & 30.65 & 29.77 & 31.62 \\
\hline & 6 To 10 & 33.47 & 29.01 & 38.46 \\
\hline \multirow[t]{4}{*}{ Driving Experience } & 11 To 15 & 22.18 & 21.37 & 23.08 \\
\hline & 16 To 20 & 7.66 & 11.45 & 3.42 \\
\hline & $>20$ & 6.05 & 8.40 & 3.42 \\
\hline & $<2000 \mathrm{~km}$ & 27.42 & 22.90 & 32.47 \\
\hline \multirow[t]{2}{*}{ Average distance/week } & $\begin{array}{l}2000-4000 \mathrm{~km} \\
>4000 \mathrm{~km}\end{array}$ & $\begin{array}{l}42.34 \\
30.24\end{array}$ & $\begin{array}{l}32.83 \\
44.27\end{array}$ & $\begin{array}{l}52.99 \\
14.53\end{array}$ \\
\hline & $<5 \mathrm{hrs}$ & 35.48 & 35.88 & 35.04 \\
\hline \multirow[t]{3}{*}{ Average Driving Hours/day } & $5-9 \mathrm{hrs}$ & 37.50 & 41.22 & 33.33 \\
\hline & $>9 \mathrm{hrs}$ & 27.01 & 22.90 & 31.62 \\
\hline & $\leq 3$ Days & 9.68 & 6.87 & 12.82 \\
\hline \multirow{3}{*}{ Number of Days Driving/Week } & 3-4 Days & 30.65 & 22.90 & 39.32 \\
\hline & $\geq 5$ Days & 59.68 & 70.99 & 47.01 \\
\hline & Tanker & 40.73 & 51.15 & 29.06 \\
\hline \multirow{3}{*}{ Type of Vehicle } & Tipper & 22.98 & 16.79 & 29.91 \\
\hline & Trailer & 25.81 & 22.14 & 29.91 \\
\hline & Luxurious Bus & 10.48 & 9.92 & 11.11 \\
\hline \multirow[t]{3}{*}{ Sleep on Wheel } & No & 66.13 & 49.62 & 84.62 \\
\hline & Yes & 33.87 & 50.38 & 15.38 \\
\hline & $\leq 3 \mathrm{hrs}$ & 13.31 & 13.74 & 12.82 \\
\hline \multirow{3}{*}{ Sleeping Hours } & $4 \mathrm{hrs}$ & 24.60 & 28.24 & 20.51 \\
\hline & $\geq 6 \mathrm{hrs}$ & 62.10 & 58.02 & 66.67 \\
\hline & No & 25.40 & 11.45 & 41.03 \\
\hline Co-Driver & Yes & 74.60 & 88.55 & 58.97 \\
\hline
\end{tabular}


Table 3. Results of binary logistic regression analysis.

\begin{tabular}{cccccccc}
\hline Variable & coeff b & S.E. & Wald & p-value & Odd Ratio & lower & upper \\
\hline Intercept & -3.15331 & 1.3579 & 5.3922 & 0.02023 & 0.04271 & & \\
Age & 0.03395 & 0.1570 & 0.0468 & 0.82882 & 1.03454 & 0.7604 & 1.4073 \\
Education & 0.03044 & 0.1687 & 0.0326 & 0.85679 & 1.03091 & 0.7406 & 1.4348 \\
Licence & 0.54275 & 0.4144 & 1.7151 & 0.19032 & 1.72073 & 0.7637 & 3.8768 \\
Driving Experience & 0.14630 & 0.1755 & 0.6947 & 0.40457 & 1.15754 & 0.8205 & 1.6328 \\
Average Distance travelled/Week & 0.58808 & 0.2125 & 7.6543 & $0.00566 *$ & 1.80052 & 1.1870 & 2.7310 \\
Average driving Hours/day & -0.50380 & 0.2220 & 5.1502 & $0.02324^{*}$ & 0.60423 & 0.3910 & 0.9336 \\
Number of Days Driving/Week & 0.46623 & 0.2939 & 2.5163 & 0.11268 & 1.59397 & 0.8959 & 2.8356 \\
Type of Vehicle & -0.04141 & 0.1552 & 0.0712 & 0.78958 & 0.95944 & 0.7078 & 1.3004 \\
Sleeping on wheel & 1.28431 & 0.3639 & 12.454 & $0.00042 *$ & 3.61216 & 1.7701 & 7.3711 \\
Co-driver & 1.37093 & 0.3770 & 13.223 & $0.00028 *$ & 3.93902 & 1.8813 & 8.2471 \\
Sleeping Hours/Day & -0.02421 & 0.2243 & 0.0116 & 0.91406 & 0.97609 & 0.6288 & 1.5149 \\
\hline
\end{tabular}

*: Statistically significant.

Table 4. Binary logistic regression analysis goodness of fit results.

\begin{tabular}{cccc}
\hline Goodness of Fit & Value & Degree of Freedom & $\mathrm{p}$ \\
\hline Chi square test & 75.053 & 11 & 0.0000 \\
Hosmer and Lemeshow test & 5.149 & 8 & 0.7420 \\
-2-Log-likelihood & 267.958 & & \\
Percent correct & 70.967 & & \\
McFadden R 2 & 0.2188 & & \\
\hline
\end{tabular}

\section{Discussion}

The results show that $52.8 \%$ of the truck drivers surveyed had been involved in an injury accident higher than $40 \%$ obtained in Tanzania [6] and 37\% in Portugal [7]. The result also indicates that $80 \%$ of the truck drivers involved in road injury accident were youth below the age of 40 years. This is due to the fact that more than half of Nigeria's population are less than 30 years old [25] with a national median age of 18.3 [26]. Also, $87 \%$ have obtained a driver's license. A high percentage of involvement of truck drivers with a license in injury accident implies a problem in the procedure for issuing the license as explained by a research where a similar scenario was observed in Pakistan [13]. It is clear that fatigue contributes to the involvement of truck drivers in an accident since $44 \%$ of the drivers involved in the injury accident traveled at least a distance of $4000 \mathrm{~km}$ a week and $70 \%$ drive for at least 5 days in a week and $64 \%$ drive for more than 5hours in a day. This agrees with research which concludes that $20-50 \%$ of commercial drivers were involved in the accident due to fatigue [27]. Articulated trucks (tanker and trailer) accounts were more involved in injury accident than other truck drivers. This is in agreement with research in Australia which revealed that driving articulated vehicle increases drivers chances of been involved in a traffic accident [9]. The Tanker driver's involvement in more injury accident than other truck drivers may be associated with the hazardous material they transport causing their accident to be more severe. The result indicates that the more experienced the driver is, the less likely his involvement in an injury accident, this is similar with a result conducted in West Australia that says truck drivers with at least $10 y e a r s$ experience are $52 \%$ less likely to be involved in a road accident than less the less experienced [9]. It can also be observed that $88 \%$ of those involved in injury accident have co- drivers, this is because majority of the co-drivers are novice drivers with little experience and mostly without driver's license. $50 \%$ of those involved in injury accident had slept on the wheel at least once, which is low compared $71.8 \%$ involvement in an injury accident on low-speed roads by research conducted by Filtness et al [16].

The result in Table 4 shows that the binary logistic regression model is capable of classifying up to $70.967 \%$ of the accidents correctly. The goodness of fit results of the model shows that the model was significant since the p-value for Hosmer and Lemeshow test was found to be greater than 0.05 . The McFadden R2 value of 0.2188 for the model also signifies very good fitness as it falls between range (0.2-0.4) that describes a very good fit of the model [28].

The results in Table 3 indicate that average distance/week, average driving hours/day, sleeping on the wheel, and presence of co-driver were found to have a p-value less than 0.05 and are therefore considered statistically significant. The OR values for Sleeping on the wheel, presence of co-driver, average distance covered in a week, driving experience, age, education, license, and number of days driving in a week are greater than 1.00 , this indicates that these variables have a positive effect on drivers' involvement in an injury accident. Karacasu et al also found OR values of level of education, to positively affect the type of accident [14].

\section{Conclusion}

The survey of 248 truck drivers in Kano state Nigeria on their involvement in injury accident was modeled using a binary logistic regression. The result revealed that sleeping on wheel, presence of co-driver, average distance covered in a week, driving experience, age, education, license, and number of days driving in a week have a positive effect on driver's involvement 
in an injury accident. Average distance traveled by drivers in a week, average driving hours/day, sleeping on the wheel, and presence of co-driver were found to be statistically significant. Fatigue was found to be the major factor contributing to the driver's involvement in an injury accident in the state, and therefore policymakers should increase safety awareness among drivers by conducting seminars and organizing training sessions regularly. The result shows that drivers with driver's license are more involved in traffic accident and OR values had a positive value greater than 1 . This is because most of the drivers studied are young, less experienced and they sometimes underestimate the potential risks associated with driving situations. Also, the procedure for issuing driver's license is not efficient and drivers do not usually undergo any driving test and they easily get a license by paying some bribe. The government should, therefore, sanitize the procedure and should punish anyone involved in undermining the procedure. The instructors should also be more trained to assess the applicant's ability. It can be concluded that the involvement of drivers having co-drivers in injury accident which was supposed to reduce fatigue is by employing novice and inexperienced drivers as co-pilots. This should also stop and proper enforcement should be observed to reduce the problem. Binary logistic regression was found to be good in classifying truck driver's involvement injury accident with a reasonable level of accuracy (70\%). Experience is a significant factor in drivers' involvement in accident but in this research the respondents were randomly selected as such aged and drivers with at least 15-years of driving experience were not fully represented making experience to make fewer impacts on the model, therefore appropriate representation of each group should be employed with more data in future studies.

\section{Acknowledgment}

The authors are grateful to Assist. Prof. Dr. Cumhur AYDIN for his kind help in improving the manuscript.

\section{References}

[1] Murat Y, Șekerler A. "Modelling traffic accident data by clustering approaches". Technical Journal of Turkish Chambers of Civil Engineers, 20(3), 4759-4777, 2009.

[2] Schneider R, Ryznar R, Khattak A. "An accident waiting to happen: a spatial approach to proactive pedestrian planning". Accident Analysis and Prevention, 36(2), 193-211, 2004.

[3] Federal Road Safety Corps. "2016 Federal Road Safety Corps Annual Report". Federal Road Safety Corps, Abuja, Nigeria, 2017.

[4] Talmage J, Hudson T, Hegmann K, Thiese M. “Consensus criteria for screening commercial drivers for obstructive sleep apnea: evidence of efficacy". Journal of Occupational and Environmental Medicine, 50(3), 324-329, 2008.

[5] Chen G, Amandus H, Wu N. "Occupational fatalities among driver/sales workers and truck drivers in the united states, 2003-2008". American Journal of Industrial Medicine, 57(7), 800-809, 2014.

[6] Kircher K, Andersson J. “Truck drivers' opinion on road safety in Tanzania-a questionnaire study". Traffic Injury Prevention, 14(1), 103-111, 2013.

[7] Catarino R, Spratley J, Catarino I, Lunet N, Pais-Clemente M. "Sleepiness and sleep-disordered breathing in truck drivers". Sleeping and Breathing, 18(1), 59-68, 2014.
[8] Safe Work Australia. "Work-Related Traumatic Injury Fatalities, Australia". Safe Work Australia, Canberra, Australia, 2016.

[9] Meuleners L, Fraser M, Govorko M, Stevenson M. "Determinants of the occupational environment and heavy vehicle crashes in western Australia: A case-control study". Accident Analysis and Prevention, 99, 452-458, 2017.

[10] Edwards J, Davey J, Armstrong K. "Profiling contextual factors which influence safety in heavy vehicle industries". Accident Analysis and Prevention, 73, 340-350, 2014.

[11] Garrido R, Bastos A, De Almeida A, Elvas J. "Prediction of road accident severity using the ordered probit model". 17th Meeting of the EURO Working Group on Transportation, (EWGT 2014), Sevilla, Spain, 2-4 July 2014.

[12] Savolainen P, Mannering F, Lord D, Quddus M. "The statistical analysis of highway crash-injury severities: a review and assessment of methodological alternatives". Accident Analysis and Prevention, 43(5), 1666-1676, 2011.

[13] Batool I, Hussain G, Kanwal N, Abid M. "Identifying the factors behind fatal and non-fatal road crashes: a case study of lahore, Pakistan". International Journal of Injury Control and Safety Promotion, 25(4), 1-7, 2018.

[14] Karacasu M, Ergül B, Yavuz A. "Estimating the causes of traffic accidents using logistic regression and discriminant analysis". International Journal of Injury Control and Safety Promotion, 21(4), 305-312, 2014.

[15] Tay R, Rifaat S, Chin H. "A logistic model of the effects of roadway, environmental, vehicle, crash and driver characteristics on hit-and-run crashes". Accident Analysis and Prevention, 40(4), 1330-1336, 2008.

[16] Filtness A, Armstrong K, Watson A, Smith S. "Sleep-related Vehicle Crashes on Low-Speed Roads". Accident Analysis and Prevention, 99, 279-286, 2017.

[17] Bunn T, Slavova S, Rock P. "Association between commercial vehicle driver at-fault crashes involving sleepiness/fatigue and proximity to rest areas and truck stops". Accident Analysis and Prevention, 126, 3-9, 2019.

[18] Alavi S, Mohammadi M, Souri H, Kalhory SM, Jannatifard F, Sepahbodi G. "Personality, driving behavior and mental disorders factors s predictors of road traffic accidents based on logistic regression". Iranian Journal of Medical Sciences, 42(1), 24-31, 2017.

[19] Pour-Rouholamin M, Jalayer M, Zhou H, "Modelling singlevehicle, single-rider motorcycle crash injury severity: an ordinal logistic regression approach". International Journal of Urban Sciences, 21(3), 344-363, 2017.

[20] Umar I, Bashir S, Gora A. "Road traffic accident in kano Nigeria: a case study of kano metropolitan". Scholars Journal of Engineering and Technology, 5(12), 691-697, 2017.

[21] Bichi A, Muhammad M. Studies on Labour and Production in Kano. Editors: Muhammad M, Mukhtar M, Adamu Y, Jimoh A, Daraja Y. Land, Labour, and Economy in Kano, 1-13, Zaria, Kaduna State, Nigeria, Ahmadu Bello University Press Limited, 2014.

[22] Barau A. The Great Attractions of Kano. Kano, Nigeria, Research and Documentation Directorate, Government House Kano, 2007.

[23] Lihua D, Xinhua Z, Qing W, You'an Y. "Logistic regression for prediction and diagnosis of bacterial regrowth in water distribution system". Transactions of Tianjin University, 15(5), 371-374, 2009. 
[24] Chen H, Cao L, Logan D. "Analysis of risk factors affecting the severity of intersection crashes by logistic regression". Traffic Injury Prevention, 13(3), 300-307, 2012.

[25] He W, Goodkind D, Kowal P. "An AGING WORLD: 2015 International Population Reports". United States Census Bureau, Washington DC, 2016.

[26] World-Population-Review. "Nigeria Population 2018" http://worldpopulationreview.com/countries/nigeriapopulation/ (26.06.2018).
[27] Davidović J, Pešić D, Antić B. “Professional drivers' fatigue as a problem of the modern era". Transportation Research Part F: Traffic Psychology and Behaviour, 55, 199-209, 2018.

[28] Lee D. "A Comparison of Choice-based landscape preference models between British and Korean visitors to national parks". Life Science Journal, 10(2), 2028-2036, 2013. 